\title{
Students Enrollment in Social Work Courses in Indian Higher Educational Institutions: An Analysis
}

Dr Sanjai Bhatt ${ }^{\dagger}$

\section{Abstract}

This study aims to analyse students' enrollment in social work courses in Indian higher educational institutions. The higher education system in India is one of the world's largest systems of its kind. There are 526 social work educational institutions and 181 Universities (20 per cent) imparting social work education and training at different levels. The data from the reports of All India Survey on Higher Education for the period of 2010-11 to 2018-19 was analysed. More than half (59.12 per cent) of the institutions are teaching undergraduate courses in social work (BSW), and more than 95 per cent are teaching postgraduate courses (MSW). Male students outnumbered female students in both courses. The share of students enrolled through distance mode of education in BSW and MSW programmes is 22 per cent and 34.09 per cent, respectively. Student enrollment at the $\mathrm{M}$. Phil level has witnessed a sudden decline, but there has been a consistent increase in the Ph.D. programme. India has added around 0.36 million BSWs/MSWs in the past eight years, averaging forty-five thousand professional social workers per annum. The changes in the socio-political environment, human relationships and social space, technology, and globalisation processes and global agenda will decide the future of social work in India.

Keywords: Social Work enrolment; All India Survey on Higher Education (AISHE); Higher education; Social Work educational institutions (SWEIs); Professional Social Workers; India

\footnotetext{
+ Professor Department of Social Work, University of Delhi, Delhi, India 110007, Email: sanjaibhatt@gmail.com (C) 2021 Bhatt. This is an Open Access article distributed under the terms of the Creative Commons Attribution License (http://creativecommons.org/licenses/by/2.0), which permits unrestricted use, distribution, and reproduction in any medium, provided the original work is properly cited.
} 


\section{Introduction: Higher Education in India}

The higher education system in India has become one of the largest systems of its kind in the world. There are 993 Universities, 39931 Colleges, and 10725 Stand Alone Institutions, employing 1.41 million teachers teaching to 34 million students. The Ministry of Education, Government of India initiated an All India Survey on Higher Education (AISHE) in the year 2010-11 to build a robust database and to assess the correct picture of higher education in the country, which is now an annual system of data collection on higher education in the country. More than 95 percent of institutions are participating in AISHE. In the 2018-19 survey, out of all higher education institutions, 962 Universities, 38179 Colleges, and 9190 standalone institutions responded. While matching the census of Social Work Educational Institutions, hereinafter referred to as SWEIs (Bhatt \& Phukan, 2015), with the list of nonparticipating institutions attached with the AISHE report, it has been found that all SWEI have participated in the survey. This study has analysed the data collected about social work discipline regarding its SWEIs, student enrollment, pass-outs, general and distance mode, international students, and research degrees in social work and has examined its growth. It has attempted to explore the trends in social work education in the higher education system through AISHE reports from 2010-11 to 2018-19. However, the data in the AISHE survey on similar parameters have been collected from 2011-12 onwards. It is essential to mention here that all the data is based on the actual response by various participating universities and higher educational institutions in the survey. Though AISHE does not present exhaustive data, particularly concerning social work, it delineates the basic information on social work as an academic discipline.

The study begins with a brief discussion about higher education in social work. Following this, it discusses student enrollment in courses of social work. Then it discusses student enrollment in research courses in social work, followed by a discussion on enrollment of international students in courses of social work and the increasing trend of trained social workers in the country. The final two sections discuss the current and future status of social work.

\section{Higher Education in Social Work}

Globally, Social work is an academic discipline and practice-based profession, taught and practiced in 145 countries. During the 6th Indian Social Work Congress at the University of Delhi, it has been defined as:

Professional social work is based on democratic values, humanitarian philosophy with central focus on the human relationships and human dignity. In India, social work draws its strengths from indigenous wisdom, constitutional commitment for equality, social justice, human rights, and scientific knowledge base. Its professional practice contributes to macro-level understanding and policy change while focusing on people at the individual, group, and community levels. As a practice-based profession, its interactions enrich institutions and systems at all levels through culturally responsive interventions that aim at individual and social wellbeing. Its central concerns are empowerment of vulnerable, oppressed, and marginalised sections of our communities and as a practice, it endeavours to partake in social change, sustainable development through participatory and collaboratory processes with people in need, institutions and the state.' [National Association of Professional Social Workers in India (NAPSWI) 2018] 
Social work was considered an academic discipline in India by a social service organisation named Social Service League, founded by Narayan Mallar Joshi in 1911 when the League decided to conduct informal training programmes for volunteers engaged in social services. Their services were later utilised for relief work among people suffering from famines, epidemics, floods, and other disasters, and welfare programmes among the poor and the destitute. It had organised the first Social worker training course at Parel in Bombay, Maharashtra. Later, Sir Dorabji Tata Graduate School of Social Work, now known as Tata Institute of Social Sciences (TISS), was established as the first formal school of social work in 1936 under the leadership of Sir Clifford Manshardt. A decade after, in August 1946, the second institution of social work was established under Directorship of Ms. Nora Ventura with support of Young Women's Christian Association (YWCA) of India, Burma, and Ceylon. It was first named National YWCA School of Social Work and later Delhi school of Social Work (DSSW) as a maintained institution of University of Delhi. On the day of independence of India (15th August 1947), Kashi Vidyapeeth, Varanasi has opened the first postgraduate department of social work under the headship of Professor Raja Ram Shastri. The NAPSWI has started celebrating National Social Work Week from 15th August to 21st August since 2020. (The National Association of Professional Social Workers in India, 2021). Besides TISS and DSSW, nine out of seventeen schools of social work by the end of the decade of 1950-60 came into existence with the help of Christian missionaries in different parts of the country. These included Indore School of Social Work in Indore, 1951; Madras School of Social Work in Chennai, 1952; Stella Maria, Chennai, 1953; Nirmala Niketan in Mumbai 1955; Rajagiri School of Social Sciences in Kerala 1955; Roshini Nilayam School of Social Work, Mangalore 1960; and Center for Studies in Rural Development (CSRD) - Institute of Social Work and Research, Ahmadnagar 1961. As per the 2nd University Grants Commission (UGC) Review Committee report, there were 35 SWEI till 1975, which grew to 53 SWEls as mentioned in the Directory prepared by the PREM division of the Ministry of Social Welfare (Ministry of Social Welfare, Government of India, 1995).

It has been argued repeatedly at different forums that there has been a mushrooming of social work schools across the country without any state control affecting the quality of social work education (Singh \& Srivastava, 2005). The International Association of Schools of Social Work (2016) published its directory of schools of social work in 2012. It was based on its census of schools of social work around the world conducted in 2010. However, there was very little information about Social Work Educational Institutions (SWEIs) in India (The International Association of Schools of Social Work, 2016). There was no official and authentic information on the exact number of institutions offering social work education in the country. As of 2013, while there was no information on the exact number of SWEIs; educators estimated as high as around 650 SWEIs (Bodhi \& Tripura, 2013). However, Bhatt and Phukan (2015) have conducted the first detailed census of SWEIs and reported 526 SWEls imparting social work education and training at different levels graduation (BSW), post-graduation (MSW), M.Phil and PhD. The zone-wise disaggregated data of SWEIs in India is presented in Table 1.

Data shows that South India, which consists of five states and one UT, has the largest number of SWEIs (46.39 per cent), whereas North India, which has the maximum number of states (five and three UTs), has comparatively fewer number of SWEls (5.13 per cent). The second-largest group of SWEls (19.39 per cent) is located in the West zone (Gujarat, Goa, and Maharashtra). In the Eastern zone, there are four SWEI each in the states of West Bengal, Jharkhand, and Bihar, which have witnessed the establishment of SWEls in the past decade; only Odisha has nine SWEls, and one is too old. Overall the Eastern zone has the lowest number of SWEIs (3.99 percent). Further, the northeastern states known as the land of seven sisters and Sikkim, which constitutes the North-eastern zone (4.18 percent), have also witnessed rapid changes as far as the establishment of SWEls is concerned. 
The first school of social work in the North eastern zone, TISS was established at the beginning of the decade of 1991-2000, and it took a little more time to stabilise, but the growth of SWEls in the NE zone has been consistent. TISS has opened its two campuses in this zone, first in Guwahati and then in Nagaland in association with Nagaland Gandhi Ashram. In 22 years, there are 22 SWEIs in Northeast states, and three more are in the offing (Bhatt \& Phukan, 2016).

The Ministry of Education (MoE), in response to a question in Parliament has informed that the UGC has informed that there are 181 universities offering different programmes in the discipline of social work (MoE, 2021). The AISHE reports provide specific information about the specialisation-wise number of colleges, and this information is compiled for 31 subjects in the AISHE. Information on colleges having Social work as a specific subject was first included in the AISHE year 2016-17, reporting 26 Social Work colleges. In the survey of 2017-18, the numbers have increased to 45 , and in 2018-19 it again grew to 47 as specialised college. (Table 2 ) It is to be mentioned that there are a few subjects who have even lesser number of colleges than social work in the latest survey such as Fisheries (23), Home Science (17) and Journalism and Communication (10). The data indicates that there are almost nine per cent specific social work colleges.

\begin{tabular}{|c|c|c|c|}
\hline Zone & States \& Union Territories & $\begin{array}{l}\text { Number of } \\
\text { SWEls }\end{array}$ & Percentage \\
\hline North & $\begin{array}{l}\text { Chandigarh (UT), Delhi, Haryana, Himachal } \\
\text { Pradesh, Jammu \& Kashmir, Punjab, Rajasthan }\end{array}$ & 27 & 5.13 \\
\hline West & Goa, Gujarat, Maharashtra & 102 & 19.39 \\
\hline Central & $\begin{array}{l}\text { Chhattisgarh, Madhya Pradesh Uttarakhand, } \\
\text { Uttar Pradesh }\end{array}$ & 110 & 20.91 \\
\hline East & Bihar, Jharkhand, Odisha, West Bengal & 21 & 4.00 \\
\hline $\begin{array}{l}\text { North- } \\
\text { East }\end{array}$ & $\begin{array}{l}\text { Arunachal Pradesh, Assam, Manipur, Meghalaya, } \\
\text { Mizoram, Nagaland, Sikkim, Tripura }\end{array}$ & 22 & 4.18 \\
\hline South & $\begin{array}{l}\text { Andhra Pradesh, Karnataka, Kerala, Pondicherry } \\
\text { (UT), Tamil Nadu, Telangana }\end{array}$ & 244 & 46.39 \\
\hline & Total & 526 & 100.00 \\
\hline
\end{tabular}

\begin{tabular}{l|c|c|c|}
\hline \multirow{2}{*}{ Table 2: Number of Social Work Colleges as Specialised College } \\
\hline States/UT & \multicolumn{3}{|c|}{ Number of Colleges } \\
\cline { 2 - 4 } & $\mathbf{2 0 1 6 - 1 7}$ & $\mathbf{2 0 1 7 - 1 8}$ & $\mathbf{2 0 1 8 - 1 9}$ \\
\hline Assam & 1 & 1 & 1 \\
\hline Gujarat & 5 & 13 & 11 \\
\hline Karnataka & 5 & 11 & 12 \\
\hline Maharashtra & 13 & 18 & 19 \\
\hline Manipur & 1 & 1 & 1 \\
\hline Odisha & - & - & 2 \\
\hline Tamil Nadu & 1 & 1 & 47 \\
\hline
\end{tabular}

Source: Report of the AISHE 2018-19, Table 4 (a) 
The number of colleges exclusively and specifically for social work education increases, indicating its demand and recognition. However, one of the aims of the National Education Policy (NEP) is to increase the Gross Enrolment Ratio in higher education. By 2030, the main thrust of this policy in higher education is to end the fragmentation of higher education by transforming higher education institutions into large multidisciplinary universities, colleges, and HEl clusters, each of which will aim to have 3,000 or more students (Para 10.1, NEP,2020). By 2030, there will be at least one large multidisciplinary $\mathrm{HEI}$ in or near every district. Thus, the aim is to increase the Gross Enrolment Ratio in higher education (including vocational education), from 26.3 per cent (2018) to 50 per cent by 2030 (Ministry of Human Resource Development, Government of India, 2020; Para10.7).

\section{Student Enrollment in Social Work programmes/Courses}

The teaching and training of social work were started at the postgraduate level, and the courses at the undergraduate level were introduced at a later stage. Bachelor's courses in Social Work were started, mostly after 1960. During the decade of 1960-70, at least five SWEI have started social work courses at the undergraduate level. Lakshmanna (1979) has categorised social work education at the undergraduate level into three patterns-(a) as one of the optional subjects, at B.A. Level. (b) As a full-fledged three-year professional course in social work leading to a Bachelor of Social Work degree. (c) As an integrated social work programme with Social Work being the main and other social sciences as ancillary subjects: Sociology, Psychology, Economics, Home Science (Lakshmanna, 1979: 146-52).

\section{Student Enrollment in Undergraduate Programme in Social Work (BSW)}

At undergraduate level, the degree in social work is called Bachelor of Social work (BSW) and at postgraduate level, it is most popularly called
MSW even some universities are granting Master of Arts in Social work. Bhatt and Phukan (2016) have reported that ' 84 SWEI are offering the BSW programme exclusively, 202 SWEls offering BSW and MSW programmes, and 25 SWEls with BSW programme, MSW, and Research courses'(2016: 61). The undergraduate courses in social work are now taught in more than half ( 59.12 per cent), 311 out of 526 SWEls of the country. An analysis of data from 2010-11 to 2018-19 (Table 3) related to Student Enrollment in Social Work at undergraduate level in Bachelor of Social work (BSW) reveals that the enrollment in the BSW programme has recorded a 583 per cent increase in mere nine years, that is, from 9921 students in 2010-11 to 67086 students in 2018-19. While the male students (53.38 per cent) have outnumbered female students (46.62 per cent) in these nine years, almost 0.3 million of students have been enrolled in BSW courses. This has contradicted a prevalent myth that females dominate the social work profession like nursing and school teaching. On average, there are 107 students per college per year enrolling in the BSW programme, as 298233 students have taken in 311 colleges in the last nine years.

\section{Student Enrollment in Postgraduate Programme in Social Work (MSW)}

The post-graduation courses are quite popular in higher education, known as MSW degree or M.A in Social work. An analysis of the data kept in Table 4 shows that the student enrollment in Social Work at the postgraduate level (Master in Social work) has also recorded a 69.09 per cent consistent increase in the past nine years as the number of enrollment has reached 28807 in 2010-11 to 48543 in 2018-19. However, there have been skewed numbers favouring male students as their numbers have been more (54.55 per cent) compared to a female student (45.45 per cent) in the past nine years from 2010-11 to 2018-19. 


\begin{tabular}{|c|c|c|c|c|}
\hline \multicolumn{2}{|l|}{ Table 3: Student Enrollment in Social Work At Undergraduate Level (Bachelor in Social Work) } \\
\hline Reporting year & Male & $\begin{array}{c}\text { Students Enrolled } \\
\text { Increase/ }\end{array}$ & $\begin{array}{c}\text { Female } \\
\text { Decrease } \\
\text { In per cent }\end{array}$ \\
\hline $2010-11$ & 5917 & 4004 & 9921 & + \\
\hline $2011-12$ & 8309 & 6286 & 14595 & 46.88 \\
\hline $2012-13$ & 21482 & 17297 & 38779 & 290.88 \\
\hline $2013-14$ & 9586 & 8253 & 17389 & 75.27 \\
\hline $2014-15$ & 10206 & 9533 & 19739 & 98.96 \\
\hline $2015-16$ & 10706 & 9689 & 20395 & 105.57 \\
\hline $2016-17$ & 27461 & 22299 & 49760 & 401.56 \\
\hline $2017-18$ & 31440 & 28679 & 60119 & 505.98 \\
\hline $2018-19$ & 34101 & 32985 & 67086 & 583.49 \\
\hline Total & 159208 & 139025 & 298233 & \\
\hline Percent & 53.38 & 46.62 & 100.00 & \\
\hline
\end{tabular}

Source: Data has been extracted from the Reports of AISHE for 2010-11 to 2018-19. For calculating changes in enrollment, the base year was 2011-12

However, this trend had slightly moved in favour of female students ( 52.80 per cent) first time in 2017-18. It is also to be mentioned that there was two per cent more enrollment in 2014-15 (71.27 per cent) concerning enrollment in 201819 (69.09 per cent). Comparing the data of enrollment in BSW and MSW programme in nine AISHE reports from $2010-11$ to $2018-19$, it is a noticeable feature that there is almost one hundred thousand more (precisely 97238) students enrollment in the MSW programme in comparison to BSW programme as there were 395561 students enrolled in MSW programme against 298233 students at BSW courses in past nine years from 2010-11 to 2018-19).

\begin{tabular}{|c|c|c|c|c|}
\hline \multirow[t]{2}{*}{ Reporting year } & \multicolumn{3}{|c|}{ Number of Students Enrolled } & \multirow{2}{*}{$\begin{array}{l}\text { Increase/ } \\
\text { Decrease } \\
\text { In percent }\end{array}$} \\
\hline & Male & Female & Total & \\
\hline 2010-11 & 18791 & 10016 & 28807 & + \\
\hline 2011-12 & 21607 & 14399 & 36006 & 25.00 \\
\hline 2012-13 & 24482 & 18042 & 42524 & 58.03 \\
\hline 2013-14 & 26188 & 20975 & 47163 & 63.72 \\
\hline 2014-15 & 26876 & 22463 & 49339 & 71.27 \\
\hline 2015-16 & 25166 & 22302 & 47468 & 64.78 \\
\hline 2016-17 & 25501 & 23042 & 48543 & 68.51 \\
\hline 2017-18 & 24176 & 22824 & 47000 & 63.15 \\
\hline \multirow[t]{3}{*}{ 2018-19 } & 22994 & 25717 & 48711 & 69.09 \\
\hline & 215781 & 179780 & 395561 & \\
\hline & 54.55 & 45.45 & 100.00 & \\
\hline
\end{tabular}

Source: Data has been extracted from the Reports of AISHE for the years 2010-11 to 2018-19. For calculating changes in enrollment, the base year was 2011-12. 


\section{Student Enrollment in Social work Courses (BSW and MSW) through Distance Education}

Professional social work education through distance learning mode is five decades old. In India, the first Bachelor Degree Programme in social work through open and distance learning (ODL) was launched by Indira Gandhi National Open University (IGNOU) in 2004. The School of Social Work (SOSW) was established on 16 August 2007, with the approval of the president of India who is also a visitor of the university (Thomas, 2015). It is the first school of Social Work in India to take social work education to all the States and Union Territories in the country as well as to SAARC and African nations. It has indigenously developed high-quality SelfInstructional Materials (SIM) and uses a multimedia approach to impart social work teaching and training in English and Hindi (IGNOU, 2019). The school currently offers eight programmes of study in social work and two on HIV and family education to 30,000 students in eight programmes. There are around 20 universities providing courses in social work (Thomas, 2015). The social work courses in distance learning/open learning universities have the same mission as conventional higher education institutions-to provide a quality education through open and distance learning using multipronged strategies and services to reach the unreached with an emphasis on social work values and ethics whereby improving the services in social welfare sectors.

An analysis of data (Table 5) in the past eight years (2011-12 to 2018-19) related to student enrollment in social work at undergraduate (Bachelor in Social Work) and postgraduate level (Master in Social work) through distance education mode demolishes a few commonly prevalent myths and misconceptions. The first and foremost notion it demolished that there is an equal or more number of students enrolled in social work education through distance mode, and these institutions have outnumbered the students' enrollment in conventional universities. Data shows that the share of students enrolled through distance mode of education in the BSW programme is even less than one-fourth (22 per cent), and in the MSW programme, it is slightly more than one-third (34.09 per cent). Rajasekharan Pillai, former Vice-Chancellor of Indira Gandhi National Open University (2012) shared that all enrollments are in the ODL system growing fast, close to 24 per cent. Because of the reach of this mode and the opportunities, it gives to those who are already employed and seek to enhance their qualifications. Interestingly, the contribution of ODL to the gross enrolment ratio (GER) in higher education has risen to about 22 per cent (Suneja, 2012).

\begin{tabular}{|c|c|c|c|c|c|c|c|c|}
\hline \multirow{2}{*}{$\begin{array}{l}\text { Reporting } \\
\text { Year }\end{array}$} & \multicolumn{3}{|c|}{ Students enrolled in BSW } & \multirow{2}{*}{$\begin{array}{c}\text { Changes } \\
\text { in per } \\
\text { cent }\end{array}$} & \multicolumn{3}{|c|}{ Students enrolled in MSW } & \multirow{2}{*}{$\begin{array}{l}\text { Changes } \\
\text { in per cent }\end{array}$} \\
\hline & Male & Female & Total & & Male & Female & Total & \\
\hline 2010-11 & \multicolumn{8}{|c|}{ Not reported } \\
\hline 2011-12 & 2332 & 2048 & 4380 & & 10614 & 6406 & 17020 & + \\
\hline 2012-13 & 14341 & 11829 & 26170 & +497.48 & 11392 & 8658 & 20050 & +17.80 \\
\hline 2013-14 & 1926 & 2137 & 4063 & -7.23 & 11618 & 10600 & 22218 & +30.54 \\
\hline 2014-15 & 1887 & 2196 & 4083 & -6.78 & 10222 & 9850 & 20072 & +17.93 \\
\hline 2015-16 & 2317 & 2433 & 4750 & +8.44 & 8296 & 7973 & 16269 & -4.41 \\
\hline 2016-17 & 3774 & 2730 & 6504 & +48.49 & 7839 & 7145 & 14984 & -11.96 \\
\hline 2017-18 & 4349 & 2978 & 7336 & +67.48 & 6794 & 5530 & 12324 & -27.59 \\
\hline \multirow[t]{2}{*}{ 2018-19 } & 4746 & 4141 & 8887 & +102.89 & 5179 & 6734 & 11913 & -30.00 \\
\hline & 35672 & 30492 & 66173 & & 71954 & 62896 & 134850 & \\
\hline
\end{tabular}

Source: The data was extracted from the Reports of AISHE for the years 2011-12 to 2018-19. The data for 2010-11 was not reported in this regard. For calculating changes in enrollment, the base year was 2011-12 
However, the segregated data of the pass percentage of students enrolled through distance mode is not available; the experts say that it is much lower in distance mode of education (around 20 per cent) in comparison to a conventional higher educational institution ( $90+$ per cent ). There may be many reasons for this, yet it is predominantly 'casualness, low fees, poor monitoring, and poor management', Further, another noticeable fact is that there is a continuous decline (-30 per cent) in the enrollment of students at postgraduate level (MSW) since 2015-16.

\section{Student Enrollment in Research Degree Courses in Social Work}

The Master of Philosophy (M Phil) and Doctor of Philosophy (Ph.D.) are two research degree programmes in the higher education system. The Ph.D. is an advanced qualification than the $M$ Phil. M Phil is where the student is expected to master a content area and can be completed in two years' full-time study. The $M$ Phil dissertation usually is shorter than the Ph.D. thesis.

An analysis of data presented in Table 6 shows that Student Enrollment in Social Work at the M.Phil level has witnessed a 70 per cent increase in enrollment till 2017-18 but a sudden decline, almost half enrollment in 2018-19 (343 in 201819 from 641 in 2017-18). This was due to widespread news that UGC is planning to scrap the M.Phil degree from the higher education system. This news appeared to be correct as National Education Policy 2020 has marked its unceremonious farewell. There has been a consistent increase in numbers of enrollment in the Ph.D. programme, as a 38.15 per cent increase was reported in 2018-19 overenrollments in 2011-12. The enrollment is bound to increase as UGC has announced many changes in admission rules, more Junior Research Fellowships, mandatory requirement for qualification for appointment of assistant professor, and more weightage in career promotions schemes.

\begin{tabular}{|c|c|c|c|c|c|c|c|c|}
\hline & \multicolumn{3}{|c|}{ Enrollment in M.Phil } & \multirow{2}{*}{$\begin{array}{l}\text { Changes } \\
\text { in } \\
\text { per cent }\end{array}$} & \multicolumn{3}{|c|}{ Enrollment in PhD } & \multirow{2}{*}{$\begin{array}{l}\text { Changes } \\
\text { in per cent }\end{array}$} \\
\hline & Male & Female & Total & & Male & Female & Total & \\
\hline 2010-11 & \multicolumn{7}{|c|}{ Data Not reported } & \\
\hline $2011-12$ & 184 & 193 & 377 & + & 200 & 222 & 422 & + \\
\hline $2012-13$ & 194 & 222 & 416 & +10.34 & 162 & 203 & 365 & -13.50 \\
\hline 2013-14 & 123 & 178 & 301 & -20.16 & 171 & 166 & 337 & -20.14 \\
\hline 2014-15 & 215 & 234 & 449 & +19.09 & 203 & 277 & 480 & +13.74 \\
\hline 2015-16 & 248 & 315 & 563 & +49.34 & 314 & 276 & 590 & +39.81 \\
\hline 2016-17 & 359 & 317 & 676 & +79.31 & 400 & 308 & 708 & +67.77 \\
\hline 2017-18 & 339 & 302 & 641 & +70.02 & 375 & 292 & 667 & +58.05 \\
\hline \multirow[t]{2}{*}{ 2018-19 } & 160 & 183 & 343 & -9.01 & 345 & 238 & 583 & +38.15 \\
\hline & 1822 & 1944 & 3766 & & 2170 & 1982 & 4152 & \\
\hline
\end{tabular}

Source: The data was extracted from the Reports of AISHE for the years 2011-12 to 2018-19.

The data for 2010-11 was not reported in this regard. For calculating changes in enrollment, the base year was 2011-12.

\section{International Students' Enrollment in Social Work Courses}

In 2018-19, 47,427 international students from 164 different countries were enrolled in higher education, with the highest share from Nepal (26.88 per cent). On the other hand, social work has a minimal share (1.50 per cent). While Social work has grown up as an academic discipline in western universities, it is still considered a young discipline in India. However, many schools of social work in India have been a destination for academic collaboration, student exchange, and 
educational visits by international students for short-term, non-formal, and friendly learning opportunities.

Data (Table 7) shows that there is a consistent increase of students in MSW courses coming from foreign countries in the past nine years. There has been very low enrollment for BSW courses. A few reasons for low enrollment of international students in social work courses are stricter course structure, longer duration of the course ( 2 years two months on account of Block fieldwork), and the more developmental thrust of the course). The duration of academic programmes in India also does not coincide with the academic calendar of western universities.

\begin{tabular}{|l|c|c|c|c|c|c|}
\hline \multirow{4}{*}{ Reporting Year } & Table 7: International Students' Enrollment in Social Work Courses \\
\cline { 2 - 7 } & Male & Female & Total & Male & Female & Total \\
\hline $2010-11$ & 48 & 33 & 81 & 15 & 06 & 19 \\
\hline $2011-12$ & 18 & 08 & 26 & 09 & 13 & 22 \\
\hline $2012-13$ & 07 & 15 & 22 & 12 & 13 & 25 \\
\hline $2013-14$ & 11 & 14 & 25 & 33 & 07 & 40 \\
\hline $2014-15$ & 06 & 14 & 20 & 21 & 22 & 43 \\
\hline $2015-16$ & 09 & 16 & 25 & 10 & 18 & 28 \\
\hline $2016-17$ & 24 & 22 & 46 & 19 & 21 & 40 \\
\hline $2017-18$ & 23 & 28 & 51 & 26 & 22 & 48 \\
\hline $2018-19$ & 33 & 53 & 86 & 35 & 27 & 62 \\
\hline Total & 179 & 203 & 382 & 180 & 149 & 327 \\
\hline
\end{tabular}

Source: The data was extracted from the Reports of AISHE for the years 2011-12 to 2018-19

\section{Trained Social Workers: An Ever Increasing Workforce}

The social work profession in India has passed through various stages - charity, welfare, development, to empowerment. The changing focus has also created situations and demands for changes in the approach, curriculum, teaching, and training pedagogies. The state has also accepted and switched its policies and programmes from welfare to the right based development and empowering approaches. Therefore, the changing countenance of State, market, and civil society organisations has asked for changes in the training of professional social workers. An analysis of data related to Outturn/Pass out of Students in Social Work Courses has revealed that 161762 students have passed out MSW in the past eight years averaging twenty thousand professional social workers per year and around one hundred thousand graduates of social work (average twelve thousand seven hundred per year). Comparing to enrollment, the pass percentage for undergraduate and postgraduate students is found to be 34 per cent. The absence of segregated data of pass-out students from mainstream education and distance education separately may be due to a lesser percentage of pass-out through distance education. Further, the courses also require extra efforts to meet their challenging fieldwork and research requirements.

As mentioned earlier, research courses in social work require a stipulated time of two years for M Phil and four years for a Ph.D. Therefore, the pass percentages are too low since these courses are rigorous, demanding apt attention, systematic devotion, and hard work. Based on combined data of the past eight years, a crude estimation shows that the pass percentage of students enrolled in the M.Phil programme is $\mathbf{5 6}$ per cent, with female students (54.71 per cent) outnumber male students (54.27 per cent). However, the variation is not much significant.

As far as students enrolled for a higher degree is concerned, the pass out the percentage of 
students enrolled in the Ph.D. programme in social work has been found relatively low (16 per cent), which means that one out of six students, completes the highest degree course. Many students are not able to complete their PhD degree because of a few known reasons. A student can complete the $\mathrm{PhD}$ degree within the period of two to six years. Since there are limited number of scholarships, a good number of students leave the idea of pursuing $\mathrm{Ph} D$ programme due to non-availability of financial support during the course of the study. Because of the lesser job opportunities in teaching and research field, a substantial number of students joins the job and they do not find enough time to complete the $\mathrm{PhD}$ programme.

\begin{tabular}{|c|c|c|c|c|c|c|}
\hline \multirow[t]{2}{*}{ Reporting year } & \multicolumn{3}{|c|}{ BSW course } & \multicolumn{3}{|c|}{ MSW course } \\
\hline & Male & Female & Total & Male & Female & Total \\
\hline 2011-12 & 3111 & 2118 & 5229 & 11345 & 6802 & 18147 \\
\hline 2012-13 & 34717 & 25194 & 59911 & 13409 & 8217 & 21626 \\
\hline $2013-14$ & 2885 & 2093 & 4978 & 13150 & 8427 & 21577 \\
\hline 2014-15 & 2447 & 2007 & 4454 & 11064 & 7766 & 18830 \\
\hline 2015-16 & 2681 & 2115 & 4796 & 11403 & 8516 & 19919 \\
\hline 2016-17 & 2573 & 2567 & 5140 & 11104 & 9676 & 20780 \\
\hline 2017-18 & 2468 & 2581 & 5049 & 10054 & 10225 & 20279 \\
\hline 2018-19 & 6141 & 6475 & 12616 & 9728 & 10876 & 20604 \\
\hline Total & 57023 & 45150 & 102173 & 91257 & 70505 & 161762 \\
\hline In Percentage & 55.81 & 44.19 & & 56.41 & 43.59 & \\
\hline
\end{tabular}

Source: The data was extracted from the Reports of AISHE for the years 2011-12 to 2018-19. The data for 2010-11 was not reported in this regard. For calculating changes in enrollment.

\begin{tabular}{|l|c|c|c|c|c|c|}
\hline \multicolumn{7}{|l|}{ Table 9: Out turn/Pass out of Students in Social Work at M.Phil and Ph.D. level } \\
\hline Reporting Year & Male & Memale & Total & Male & Female & Total \\
\hline $2011-12$ & 108 & 80 & 188 & 17 & 22 & 39 \\
\hline $2012-13$ & 126 & 102 & 228 & 25 & 29 & 54 \\
\hline $2013-14$ & 105 & 149 & 254 & 27 & 30 & 57 \\
\hline $2014-15$ & 127 & 137 & 264 & 52 & 53 & 105 \\
\hline $2015-16$ & 107 & 131 & 238 & 61 & 50 & 111 \\
\hline $2016-17$ & 153 & 187 & 340 & 62 & 46 & 108 \\
\hline $2017-18$ & 164 & 204 & 368 & 54 & 47 & 101 \\
\hline $2018-19$ & 107 & 132 & 239 & 57 & 52 & 109 \\
\hline Overall pass outs & 997 & 1122 & 2119 & 355 & 329 & 684 \\
\hline Overall enrollment & 1822 & 1944 & 3766 & 2170 & 1982 & 4152 \\
\hline $\begin{array}{l}\text { Percentage of pass } \\
\text { out }\end{array}$ & 54.72 & 57.71 & 56.26 & 16.35 & 16.60 & 16.47 \\
\hline Source: The data was extracted from the Reports of AlSHE for the years 2011-12 to 2018-19. \\
\hline The data for 2010-11 was not reported
\end{tabular}

\section{Social Work Today}

India is the second-largest country globally, having $526+$ social work educational institutions offering social work education programmes in the central, state, private \& deemed universities and colleges in most of the states and union territories. Social work is well known academic discipline in India and is regarded as one of the best job-oriented courses in the university 
system at different levels - undergraduate, postgraduate, and research. Almost three of the fourth students get jobs in Government and nongovernment social sectors and the corporate sector soon after the completion of their course.

The Indian professional social work community is raucously advocating for enacting legislation to establish a national council for social work education (NCSWE) in India. It is expected that the establishment of the council shall lead to enhance quality in social work education, including its linkages with practice, knowledge, and ethical conduct. It has also demanded that national registers of accredited social work education institutions, programmes, and professionals should be created. The need for a trained workforce for the social sector has been more prominent in post globalisation society. Social work is currently taught as an academic discipline in colleges and universities spread over 145 countries. Most of these countries have a National Council for Social Work.

The 9th report of All India Survey of Higher Education 2018-19 have reported more than one hundred thousand students enrolled in BSW and MSW courses in 2018-19, and close to seven hundred thousand in nine years. Over five hundred thousand professional social workers are estimated to be currently working with civil society organisations, Government, corporate sector, hospital and health sectors, and the other welfare/developmental agencies at the state, regional, national, and international levels. Professional social workers have been recognised for various jobs under various legislations. A few prominent ones are Welfare Officer under Factories Act, 1948 (Sec 49), counsellors under The Family Courts Act, 1984 (Sec 6), The Juvenile Justice (Care and Protection of Children) Act, 2015 (Sec 4), Psychiatric Social Workers under the Mental Healthcare Act 2017 (Sec 43), Transplant coordinators under Transplantation of Human Organs and Tissues Act 2014 (Sec29).In the recently legislated National Commission for Allied and Healthcare Professions Act, 2021, Social workers, including Clinical Social Worker, Psychiatric Social Worker, Medical Social Workers, are brought under the category of Behavioural Health Sciences professionals. During COVID -19, the community of professional social workers has contributed to providing essential and emergency support services, including awareness.

Professional social workers are playing an essential role in managing relief and rehabilitation in disasters/pandemics. A large number of social workers are involved in the fields of child protection, criminal justice, mental health, women victims of violence, community development, drug de-addiction, legal systems, and alternate dispute redressal, empowering processes, social reform, and social actions. There are many other fields where social workers are making a significant contribution. In the absence of the National Council of Social Work Education, it is difficult to maintain quality standards. Hence, there is a need to strengthen social work education in the country. The National Education Policy 2020 emphasises on creation of Professional Standard-Setting Bodies and has also promised employment opportunities for the engagement of trained social workers through a newly proposed structure of the School Complex. Professional social workers can significantly contribute to the Government's vision which envisages a New India by 2022 , not only by eradicating poverty and corruption through inclusive and sustainable development but also through becoming part of many programmes for social-economic development in mission mode by the present Government specifically in the field of education, health, mental health, skill, employment, human resources, welfare, social justice, empowerment, etc. Desai and Narayan (1998) have cautioned that:

There is an urgent need for social work professionals, new and old, to engage in a review process and retrain themselves to the developmental perspective of intervention and the strategies required, in order making practice more meaningful to meet the needs of the changing social realities. The priorities need to be rearranged so 
that the primary problems affecting the masses receive greater focus than the other issues. These challenges will also have to be dealt with by institutions for social work education, the professional associations in social work, the proposed National Council of Social Work, the next UGC Review Committee of social work education, the next Encyclopedia of Social Work, and other structures and processes that influence the profession (Desai \& Narayan, 1998, p. 558).

\section{Future of Social Work Education in India}

Social Work education in the Indian university education system will be a century-old in another 15 years. Today, the million-dollar question is about the future of social work when it will be 100 years old in India in 2036. Unfortunately, the social work community has neither researched much of its various aspects nor any higher education agency like the UGC has so far initiated any meaningful discussion. However, the future of social work can be predicted on the basis of data related to enrollment of students in social work courses, the vision of higher education enshrined in National Education Policy 2020, and other changes in the field of social work education and practice. It appears that the social work education and practice in the coming two decades will attract more students to its principal and allied courses; it will be offering more employment and securing more space in policy planning and execution of social welfare and development services. The following four dominant changes will positively influence the social work education and practice: i) changes in the socio-political environment of the country, ii) changing human relationships and social spaces iii) changes in technology and iv) changing globalisation processes and global agenda. These changes will occur in education, especially the implementation of a New Education policy, and the changing global agenda will require an extensive data set that is currently not available in desired format. Based on personal experiences and reflections clubbed with available trend analysis, the future of the social work profession shall be heavily stroked by the quantity and quality of the education and training. Quantitatively, the number of institutions imparting SWEIs may be doubled, and the present social work courses will outgrow in many sub groups specific and problem-specific courses. The emergence of specifically designed courses and services for mainly targeted groups like children, women, transgender, homeless, differently-abled, refugees, and other groups will come to stay for long. Many of these specified courses may grow as an independent knowledge area. The other academic programmes which will be offshoots of social work will be need-based such as HIV/AIDS, microfinance, social entrepreneurship, which may be categorised as problem-specific and societal response based. Some new areas may emerge such as Workplace management, Spiritual social work, Digital social work etc. The efficacy and effectiveness of services rendered by the profession shall determine the acceptability of the profession. There is a possibility of creating a new cadre of trained social work administrative services at central and state levels. The demand for qualified service providers at the grassroots level has already begun as millions of grass-root workers are already providing education and health services.

Professor Brij Mohan has talked of a knowledge man. To him, the new emerging technologies like Al, 3D, will play a more significant supportive role in the delivery of education and services. The new social service workforce will be technologically advanced, socially vital and well connected, and ethically confused. He explains that fundamental future changes with profound consequences for social work; to the new algorithms of social transformation to stave off unprecedented humanitarian crises, to the revolutionising digital progress resulting, for example, in the design of multi-functional robots which may replace humans (Mohan, 2018). Baikady, Pulla and Channaveer (2014) have observed that 'to enhance the quality of social work education in the country at the postgraduate level and meet the professional 
challenges in the social work practice, there is an urgent need for addressing the challenges and the possibilities in the social work education. There is also a need for Indian social work education to learn and adopt social work practices around the world (2014, p. 315). Social work is a skill-oriented course that would have greater need and relevance in the future, and social work administrators in higher educational institutions have to think, plan and act to reskill and upskill at various levels in the near future as per societal requirements.

The unique feature of the social work programme will be its fieldwork which may face a challenge. It will be difficult to resolve many issues without strengthening field practicum, such as social work is a vocation or profession. In the future, the specialised knowledge and the skilled and competencies-based preparation of a social worker shall be a central point of emphasis in the curriculum. Professor Armaity Desai, former Chairperson, UGC, has pointed out that a social worker, to be a competent practitioner, has to develop, besides all that is imparted during training, a social commitment, social responsibility, and a desire for social justice which would eventually permeate their work with individuals and groups (Desai, 1974). The students' inculcation of this frame of mind should be the ultimate object of field instruction programmes in Social Work Education in India (Deviprasad \& Vijaylakshmi, 1997:74). Gray and Webb (2010) have opined that Social work faces an exciting but challenging future. The demands placed on social work and the changing contours of its remit will vary from place to place and across time (2010: vii). Professional social work in India has a bright future, but it must respond continuously, coherently, and comprehensively to changing contexts with clear convictions.

\section{References}

Baikady, R., Pulla, V., \& Channaveer, R. M. (2014). Social work education in India and Australia, International Journal of Social Work and Human Services Practice, 2 (6), 311-318.

Bhatt, S., \& Phukan, D. (2015). Social work education in India-a resource book. New Delhi: AlterNotes Press.
Bhatt, S., \& Phukan, D. (2016). Social work educational institutions in India: An analysis. Journal of Social Work Education, Research and Action, 2(1), 46-66.

Bodhi, S. R., \& Tripura, B. (2013). International social work - An Indian experience. Indian Journal of Dalit and Tribal Social Work, 1 (3), 124.

Desai, A. S. (1974). Social work education in India. In B. Chatterjee and S. D. Gokhale (Eds.), Social welfare: Legend and legacy. Bombay: Popular Prakashan.

Desai, M., \& Narayan, L. (1998). Challenges for social work profession towards people-centred development. Indian Journal of Social Work, 59 (1), 531-558.

Deviprasad, B., \& Vijaylakshmi (1997). Field instruction in social work education in India. Indian Journal of Social work, 58(1), 65-77.

Gray, M, \& Webb, S. A. (2010). Introduction: Future challenges. In M. Gray and S. A. Webb (Eds.), International Social Work- Volume IV: Future Challenges. SAGE Publications.

International Association of Schools of Social Work (2016). Our members.

https://www.iassw-aiets.org/ourmembers/\#1580474856533-43de923d-7ab9

IGNOU. (2019). School of Social Work. New Delhi: IGNOU

http://ignou.ac.in/ignou/aboutignou/school/so sw/introduction

Lakshmanna, M.(1979).Undergraduate Social Work Education in India: Retrospect and Prospect, Indian Journal of Social Work,50(2), 146-152.

Ministry of Social Welfare, Government of India. (1995). Directory of social work education facilities in India. New Delhi: Planning Research Evaluation and Monitoring Division, Ministry of Social Welfare.

Ministry of Education, Government of India. (2021). Response given by Minister of Education in Lok Sabha, Unstarred Question No.159, raised by Mr Harish Dwivedi, Member of Parliament, on 19.07.2021 
Ministry of Human Resource Development, Government of India. (2013). $1^{\text {st }}$ Report on All India survey on higher education (AISHE), 201011. New Delhi: Department of Higher Education, Ministry of Human Resource Development.

Ministry of Human Resource Development, Government of India. (2014). $2^{\text {nd }}$ Report on All India survey on higher education (AISHE), 201112. New Delhi: Department of Higher Education, Ministry of Human Resource Development.

Ministry of Human Resource Development, Government of India. (2015 a). $3^{\text {rd }}$ Report on All India survey on higher education (AISHE), 201213. New Delhi: Department of Higher Education, Ministry of Human Resource Development.

Ministry of Human Resource Development, Government of India. (2015 b). $4^{\text {th }}$ Report on All India survey on higher education (AISHE), 201314. New Delhi: Department of Higher Education, Ministry of Human Resource Development.

Ministry of Human Resource Development, Government of India. (2016 a). $5^{\text {th }}$ Report on All India survey on higher education (AISHE), 201415. New Delhi: Department of Higher Education, Ministry of Human Resource Development.

Ministry of Human Resource Development, Government of India. (2016 b). $6^{\text {th }}$ Report on All India survey on higher education (AISHE), 201516. New Delhi: Department of Higher Education, Ministry of Human Resource Development.

Ministry of Human Resource Development, Government of India. (2017). $7^{\text {th }}$ Report on All India survey on higher education (AISHE), 201617. New Delhi: Department of Higher Education, Ministry of Human Resource Development.

Ministry of Human Resource Development, Government of India. (2018). $8^{\text {th }}$ Report on All India survey on higher education (AISHE), 201718. New Delhi: Department of Higher
Education, Ministry of Human Resource Development.

Ministry of Human Resource Development, Government of India. (2019). $9^{\text {th }}$ Report on All India survey on higher education (AISHE). 2018-

19. New Delhi: Department of Higher Education, Ministry of Human Resource Development.

Ministry of Human Resource Development, Government of India. (2020). National Education Policy 2020. New Delhi: Ministry of Human Resource Development.

Mohan, B. (2018). The future of social workseven pillars of practice. New Delhi: SAGE Publications India.

National Association of Professional Social Workers in India. (2018). Definition of professional social work. New Delhi: NAPSWI. https://www.napswi.org/definition.html National Association of Professional Social Workers in India. (2021). $2^{\text {nd }}$ National social work week. www.napswi.org

Singh, S., \& Srivastava, S. P. (2005). Teaching and practice of social work in India- Realities and responses. Lucknow: New Royal Book Company.

Suneja, K. (2012, May 4). $25 \%$ of Indian students covered by distance education: Study. Financial Express, New Delhi.

https://www.financialexpress.com/archive/25of-indian-students-covered-by-distanceeducation-study/945204/

Thomas, G. (2015). Social work education through distance learning in India. In S. Bhatt and S. Pathare (Eds.), Social Work Education and Practice Engagement. New Delhi: Shipra Publications.

\section{Conflict of Interest}

I confirm that I have no conflict of interest

\section{Acknowledgements}

This study is dedicated to the Indian social work community who has been seeking answers to the questions related to students' enrollment in social work courses in general and particularly 
during advocacy campaigns for legislation to Pathare, and Ms. Preeti Jha for their comments establish a national council for social work and support. I am also thankful to Dr. G Mahesh education in India. I would like to thank and Dr. Atul Pratap Singh for provoking me for Professor Venkat Pulla, Professor B. Deviprasad, this research.

Professor Neera Agnimitra, Professor Suresh 